\title{
10. FAMOUS PIANISTS PERFORM BEETHOVEN 32 VARIATIONS ON AN ORIGINAL THEME IN C MINOR ACCORDING TO THE PIANISTS DANIEL BARENBOIM AND EVGENY KISSIN
}

\section{Brîndușa Tudor}

\begin{abstract}
Year 2020 constitutes an incredibly significant landmark in the classical music history as it is the year celebrating 250 years since the composer Ludwig van Beethoven was born. The "32 Variations on an Original Theme in C minor" are deemed to be some of the most brilliant pianistic works marking the second period of Beethoven creation. The interpretative visions of Daniel Barenboim and Evgeny Kissin are equally interesting, the two great pianists putting their personality, sensitivity, and culture mark. All these elements confer upon the piece "32 Variations on an Original Theme in C minor" particular expressive valences highlighting Beethoven's creative genius.
\end{abstract}

Key words: Ludwig van Beethoven, 32 Variations on an Original Theme in C minor, Daniel Barenboim, Evgeny Kissin, interpretative visions

\section{Introduction}

Year 2020 constitutes an incredibly significant landmark in the classical music history as it is the year celebrating 250 years since the composer Ludwig van Beethoven was born. The 32 Variations on an Original Theme in $C$ minor were composed in 1806 and were published in Vienna one year later. They are deemed to be some of the most brilliant pianistic works marking the second period of Beethoven creation, a period that was also marked by the composition of the piano sonatas op.53 (Waldstein), op.57 (Appassionata) and op. 81a (Les adieux/Das Lebewohl) etc. We shall analyse next the interpretative versions of some valuable contemporary pianists: Daniel Barenboim and Evgeny Kissin. Daniel Barenboim includes this piece in "On my New Piano" album released in 2016 by Universal Music Group. Evgeny Kissin performed it live within a recital held in 2007 at Verbier Festival.

\section{Theme}

These variations are written on a short theme of eight bars built through the sequencing of motive with dotted rhythm and supported by chromatic chordal basses. Daniel Barenboim opts for a slower tempo for the theme exposition, but this is not a steady one: starting with the fifth bar, he delays the second beat and lengthens the chord of the sixth bar too much, reaching a number of three beats instead of two. This interpreting vision leads to a certain fragmentation of tension that should accumulate and reach the climax through $s f$ on the fourth key - $F$ minor in the sixth bar. Even if the tempo chosen by Evgeny Kissin is more alert, this one provides the musical speech with a more balanced character, therefore succeeding in highlighting the solemn character of the theme better.

95 Associate Professor PhD., "George Enescu" National University of Arts from Iaşi, Romania, email: tudorbtindusa@yahoo.com 
The mystery atmosphere of the theme conclusion (bars seven and eight) is much better depicted by Daniel Barenboim, as this one observes the indications given by the score and does not decrease the duration of eights. At Evgeny Kissin, the mystery atmosphere is broken as this one chooses to interpret staccato all the eights in the end of the theme. In none of the editions that are supposed to observe Beethoven's original manuscript there is any indication regarding staccato: the first edition published in Vienna in $1807^{96}$ and the two Urtext editions by G. Henle publishing house $\left(1961 / 1989^{97}\right.$ și $\left.2019^{98}\right)$.

\section{Variations}

\section{Variations I - III}

In the first three variations, the interpretative versions of the two pianists are quite different both when it comes to approaching the tempo and the use of the dynamic palette. Daniel Barenboim chooses a tempo which is remarkably similar to the one used in the beginning of the piece, therefore ensuring coherence between the theme and the first variations. The pianist observes the tone of piano indicated by the score and achieves small fluctuations of crescendo and decrescendo following the melody, whether it is an ascending or descending one. At the same time, he discretely highlights the fourth key in $F$ minor, also emphasizing it by using the pedal on $s f$ of the sixth bar in the first two variations. Even if we talk about a studio recording ${ }^{99}$, starting with the second variation, the pianist loses a bit of the quality of arpeggio figures of semiquavers and repeated music notes exposed first with the left hand, then with both hands in the opposite direction.

Evgeny Kissin provides the three variations with a much more agitated character due to the much more rapid tempo compared to the one in which he interpreted the theme. Even if in none of the editions mentioned above there is not an indication regarding the change of tempo, Kissin's interpretative view impresses nevertheless by a more rhythmical accuracy, considering that it is a live interpretation. When it comes to choosing the dynamic palette, the pianist does not consider either the piano indication around which the entire musical speech is deployed. Evgeny Kissin uses much larger dynamics, even forte ones in the end of the third variation, considering it a climax of the entire section.

\section{Variation IV}

In the fourth variation, both pianists stay loyal when choosing the same tempo as in the previous variations: Daniel Barenboim keeps the slower tempo, whereas Evgeny Kissin opts for the more alert one. Throughout the entire variation, Evgeny Kissin performs the triolets in the median voice in staccato (therefore complying with the indication given by the score), whereas Daniel Barenboim achieves them legato associating them in places with the pedal (in the end of the sixth bar and the beginning of the seventh). At the same time,

\footnotetext{
${ }^{96} \mathrm{https} / /$ www.beethoven.de/en/media/view/4918633515974656/Ludwig+van+Beethoven\%2C+Variationen+\%C3\% $\mathrm{BCber}+$ ein+eigenes+Thema+f\%C3\%BCr+Klavier+\%28c-

$\mathrm{Moll} \% 29+\mathrm{WoO}+80 \% 2 \mathrm{C}+\mathrm{Bureau}+\mathrm{des}+$ Arts+et $+\mathrm{d} \% 26 \% 2339 \% 3 \mathrm{BIndustrie} \% 2 \mathrm{C}+545$ fromArchive $=629984527070$ 0032\&fromWork $=5019681077329920$

${ }^{97} \mathrm{https}: / /$ www.henle.de/en/detail/?Title $=32+$ Variations $+\mathrm{c}+$ minor+WoO+80_61

${ }^{98} \mathrm{https}: / / \mathrm{www} \cdot$ henle.de/en/detail/?Title $=32+$ Variations $+\mathrm{c}+$ minor + WoO+80_1388

${ }^{99} \mathrm{https}$ ://www.universal-music.de/daniel_barenboim/musik/on-my-new-piano-360664
} 
Barenboim does not observe the left-hand rhythm in the seventh bar, the sixteenth being performed at the same time with the eight in the right hand triolet. Even if the tempo is quite rapid, Kissin observes this rhythm, emphasizing it in an audible manner in a much clearer way than Barenboim. Both interpreters achieve the passing to the next variation through a small ritenuto in the last bar.

\section{Variation V}

Even if both pianists opted for almost the same tempo, the interpretative version chosen by Evgeny Kissin is much more suggestive. This one highlights the bass much better, and through a dynamic palette he follows the right-hand melody. Here, the staccato arpeggios associate with octaves and deploy in crescendo through a stretto effect, which leads to the creation of a tension culminating with $s f$ in $F$ minor in the sixth bar. The $S f$-s are much more obvious at Kissin, and in the end of the variation he softly emphasizes the first note from the groups of three connected eighths on each hand.

\section{Variation VI}

The version chosen by the pianist Evgeny Kissin has a little too agitated character due to the considerably rapid tempo opted for. The version embraced by the pianist Daniel Barenboim is much more balanced and impresses us by the rhythmic focus, sustained tempo and manner in which he highlights the $s f$ of the score very clearly. All these elements provide the musical speech with an obsessive nature.

\section{Variations VII - VIII}

Variation VII benefits from a much more intense interpretation according to Evgeny Kissin, due to the slower tempo and more lyrical approach through which he chooses to emphasize the right-hand melody. At the same time, the pianist dramatizes the musical speech of the two variations more, by choosing a much more diversified dynamic palette compared to the one used by Daniel Barenboim. The emphasis of the fourth key in $F$ minor in the sixth bar of both variations is less obvious in the interpretative version of the pianist Daniel Barenboim, as it creates a gap between the left hand and the right one.

\section{Variation IX}

Both pianists perform this variation with much sensitivity, in a delicate manner that highlights the espressivo nature of the musical discourse.

\section{Variations X - XI}

Even if there are but few differences when it comes to choosing the tempo (Kissin preferring once again a more alert tempo), both interpretative versions render the energic power of these two variations. Even if in the score there is no agogic indication, Daniel Barenboim chooses to prepare the piano from the next variation by a ritenuto in the end of variation XI, therefore achieving the fortepiano contrast much better. Evgeny Kissin does not take into account the piano indication from the bass in variation XII, the transition towards this one being achieved in tempo, with no agogic preparation.

\section{Variation XII}

Daniel Barenboim is much more expressive in his interpreting and captures better the calmer, the quieter nature of this variation, which is reflected by Beethoven both through the tonal contrast ( $C$ major), and the return to the 
presentation of the theme in chordal structure on descending chromatic basses.

\section{Variation XIII}

Both interpretative visions are interesting, the two pianists emphasizing the calm nature and closely following both the theme exposed at the left hand, and the melody keys from the figurations of right-hand sixteenths.

\section{Variation XIV}

Even if we may consider this variation to be an ornamental version of the previous one, the theme and figurations being brought into harmonic thirds, Evgeny Kissin does not keep the same tempo, opting for a more rapid one. This results in discontinuity from the point of view of nature and harmonic-melody construction.

\section{Variations XV - XVI}

In Daniel Barenboim's interpretative version, the two variations flow better, the pianist performing at the right hand an expressive legato at the bottom of the keyboard that follows the melodic figurations of syncopated octaves (variation $\mathrm{XV}$ ) and octaves off-beat (variation XVI).

\section{Variation XVII}

In this variation that comes back to minor tonality ( $C$ minor), both pianists performs in a more delicate manner the themes exposed in two voices in an imitative dialogue, first at all at the right-hand, then towards the ending at the lefthand.

\section{Variation XVIII}

The energic nature of this variation is emphasised in both versions, the two pianists performing the entire section in a truly clear, balanced and rhythmical manner, by paying special attention to the quality of forte dynamics.

\section{Variation XIX}

Through his performance, the pianist Evgeny Kissin adds to a higher tension of the musical speech. He manages to better catch the dramatic effect created by both the forte-piano-forte contrasts and the dynamic increase in the end of variation.

\section{Variations XX - XXII}

Both interpretative versions highlight the energic, almost military nature of these variations, the two pianists emphasizing the rhythmical intensity and following the sound quality in high dynamics all the time.

\section{Variation XXIII}

The calm and quiet atmosphere characterising this variation, is emphasized in the two interpretative versions, both pianists using delicate pianissimo sonorities. What we note at Evgeny Kissin is a greater concern for a subtle focus on the melody of the right-hand figurations, which is supported by the left-hand chromatic basses.

\section{Variations XXIV - XXVII}

What differentiates the performance of the following four variations by each of the two pianists is the chosen tempo: Daniel Barenboim keeps the same tempo of the previous variation, his approach being a more balanced one. In variations XXIV and XXV, the pianist creates a more lyrical atmosphere, the entire musical speech being much calmer. In the previous variations, what we noted many times 
was Evgeny Kissin's fondness for more alert tempos, in variation XXIV however, he opted for a bit too rapid tempo. Besides that, in the following three ones his choice of the tempo is not consistent, this option conferring upon the performance restlessness.

\section{Variation XXVIII}

Due to the more slower tempo, this variation finds a more suggestive performance according to Daniel Barenboim. This one follows more sensibly the melody exposed on the right-hand and overlaid on a very delicate left-hand accompaniment.

\section{Variation XXIX}

Even if both interpretative visions share an energic nature, the version embraced by the pianist Evgeny Kissin has a greater impact due to the clarity of the attack and rhythmical accuracy in a much more alert tempo compared to the one chosen by Daniel Barenboim. The two pianists use a different performance to mark the transition between this variation and the next one, both versions being equally interesting: even if in the score there is no agogic or dynamic indication in the end of variation XXIX, Evgeny Kissin choses to prepare pianissimo from variation XXX through a decrescendo associated with poco ritenuto. Daniel Barenboim observes the indications given by the score and makes a direct transition, therefore achieving the fortissimo - pianissimo dynamic contrast, which in fact is quite difficult from the technical point of view.

\section{Variation XXX}

Compared to the previous variation, this variation brings a powerful contrast by the chordal writing with contrary chromatic direction, both pianists emphasizing the peaceful character and softly marking the melody notes from the right-hand higher voice.

\section{Variations XXXI - XXXII}

In the latest two variations, the entire timbral-coloristic richness of the piano is exploited in both performances, starting with pianissimo mysterious sonorities, achieved with much refinement, and culminating with fortissimo, therefore obtaining sound effects loaded with dramatism. To draw a conclusion here, both interpretative visions of this piece are equally interesting, the two great pianists putting their personality, sensitivity, and culture mark. All these elements confer upon the piece 32 Variations on an Original Theme in $C$ minor particular expressive valences highlighting Beethoven's creative genius.

\section{References}

1. Alşvang, Alexei, (1961), Beethoven, Editura Muzicală, Bucureşti

2. Antal, Frederick, (1971), Clasicism şi romantism, Editura Meridiane, București

3. Barenboim, Daniel, (2015), Daniel Barenboim. O viață în slujba muzicii, Editura Humanitas, București

4. Bentoiu, Pascal, (1975), Gândirea muzicală, Editura Muzicală, Bucureşti

5. Berger, Wilhelm Georg, (1981), Estetica sonatei clasice, Editura Muzicală, Bucureşti 
6. Berger, Wilhelm Georg, (1987), Teoria generală a sonatei, Editura Muzicală, Bucureşti

7. Bughici, Dumitru, (1974), Dicţionar de forme şi genuri muzicale, Editura Muzicală a Uniunii Compozitorilor, Bucureşti

8. Chelaru, Carmen, (2007), Cui i-e frică de Istoria muzicii?!, Editura Artes, Iaşi

9. Ciocan, Dinu, (2006), O teorie semiotică a interpretării muzicale, Editura Universităţii Naţionale de Muzică, Bucureşti

10. Dinicu, D. Gh, (1963), Contribuţii la arta interpretării muzicale, Editura Muzicală, Bucureşti

11. Duţică, Gheorghe, Duţică, Luminiţa,( 2004), Conceptul ritmic şi tehnica variaţională, Editura Artes, Iaşi

12. Hatten, Robert S., (2004), Interpreting musical gestures, topics, and tropes: Mozart, Beethoven, Schubert, Indiana University Press

13. Herman, Vasile, (1982), Originile şi dezvoltarea formelor muzicale, Editura Muzicală, Bucureşti

14. Herman, Vasile, (1973), Formele muzicale ale clasicilor vienezi, Conservatorul de Muzică Gheorghe Dima, Cluj

15. Iliuţ, Vasile, (1996), O carte a stilurilor muzicale, Editura Academiei de Muzică, Bucureşti

16. Sandu-Dediu, Valentina, (2000), Ludwig van Beethoven, Editura Muzicală, Bucureşti

17. Ștefănescu, Ioana, (1998), O istorie a muzicii universale, Editura Fundaţiei Culturale Române, Bucureşti

18. Vasiliu, Laura, (2007), Intrepătrunderea principiilor de formă; Curs de analiză muzicală, Editura Artes, Iaşi

19. Wolff, Konrad, (1990), Masters of the Keyboard: Individual Style Elements in the Piano Music of Bach, Haydn, Mozart, Beethoven, Schubert, Chopin and Brahams, Indiana University Press

\section{Scores}

1. Beethoven, Louis van, (1807), Trente deux VARIATIONS pour le Pianoforte, Bureau des Arts et d'Industrie, Wien

2. Beethoven, (1961/1989), 32 Variationen c-moll WoO 80, Urtext, G. Henle Verlag

3. Beethoven, (2019), 32 Variationen c-moll WoO 80, Urtext, G. Henle Verlag

\section{Discography}

1. Barenboim, Daniel, (2016), On my New Piano, Universal Music Group

2. Kissin, Evgeny, (2007), Recital Beethoven, Brahms, Chopin and Bizet Verbier Festival, Medici.tv

\section{Web site}

1. https://en.wikipedia.org/wiki/32_Variations_in_C_minor_(Beethoven) (4.09.2020)

2. https://www.classiccat.net/beethoven_1_van/w80.info.php (4.09.2020)

3. https://imslp.org/wiki/32_Variations_in_C_minor\%2C_WoO_80_(Beethoven\% 2C_Ludwig_van) (4.09.2020) 
4. https://www.youtube.com/watch?v=O3DbqTvgX9w (4.09.2020)

5. https://www.youtube.com/watch?v=FIZWPbCZ6cQ (4.09.2020)

6. https://www.medici.tv/en/concerts/kissin-verbier-2007-beethoven-brahmschopin-bizet/ (4.09.2020)

7. https://www.lafolia.com/a-look-at-beethovens-32-variations-in-c-minor-part-i/ $(5.09 .2020)$

8. https://www.lafolia.com/a-look-at-beethovens-32-variations-in-c-minor-part-ii/ $(5.09 .2020)$

9. https://www.beethoven.de/en/work/view/5019681077329920/Thirtytwo+Variati ons+on+an+original+theme+for+piano+\%28C+minor\%29+WoO+80?fromArchiv $\mathrm{e}=6299845270700032(5.09 .2020)$

10. https://www.henle.de/en/detail/?Title $=32+$ Variations+c+minor+WoO+80_138

$8(6.09 .2020)$

11. https://www.henle.de/en/detail/?Title $=32+$ Variations $+\mathrm{c}+$ minor + WoO+80_61 (6.09.2020)

12. https://www.universal-music.de/daniel_barenboim/musik/on-my-new-piano$360664(7.09 .2020)$ 